\title{
A Present for an Apprentice
}

A Recent purchase of the George F. Baker Library, whose acquisitions are at the disposal of the Society, is entitled $A$ PRESENT For an APPRENTICE: Or, A Sure GUIDE to gain both Esteem and Estate. With Rules for his Conduct to his MASTER, and in the WORLD. Ours is a tenth edition and was printed for James Fletcher, in St. Paul's Church-Yard, and Benjamin Collins, Bookseller, on the New Canal in Salisbury. The work bears no date and is ostensibly written "By a late Lord Mayor of London," and dedicated by the editor to Sir John Barnard. However, Halkett \& Laing, on the authority of the British Museum Catalogue, attribute the authorship to the said Sir John Barnard and place the date of the work as of about 1740 .

This treatise is in the form of a lengthy letter or tract addressed to the writer's son. After commenting on the fact that he has already "done all that is necessary in the Article of Expence, for your entering gracefully on the Stage of the World," he thinks it advisable, since "Life is a Scene of Care, and Prudence generally the Child of Experience and Calamity,... to make you (his son) the Heir of what Knowledge I am possessed of, as well as my Estate, that you may be guarded against all the Snares to which Youth is liable; and that you may be as well provided with Advice in all Exigencies, as when under my Wing; or as if you had already suffered all I would teach you to avoid." He then comments upon the fact that many fathers have undertaken such a task, "but these have directed their Thought to a Pitch above the Level of your Station; and none, that I know of, stooped so low as an Apprentice; to whom, nevertheless, Advice was equally necessary."

The author pithily remarks that "Young Men are apt to think themselves wisest; but that in general is impossible, because Wisdom is the result of Time and Reflection; and Youth must, of Course, be almost as much a Stranger to the one, as the other." That the author had a deep and sympathetic understanding of human nature is apparent from his intelligent discussion of the weaknesses and foibles of mankind under such headings as "Lying," "Fidelity," "Other Peoples Quarrels," "Value of Time," "Religion," etc. He had also a considerable knowledge of the economics of business, as his advice to his son on this score amply proves. He urged him to serve first as a "journey man," mean- 
while looking about for a proper place to settle in. When this has been determined upon, should he decide to start out for himself, he cautions him to beware of "Great Rents" and "Fine-Shops." The latter, with their "Looking-Glasses," "Carvings," "Guildings," etc., have wrecked "more younger Sons of good Families and Fortunes, from two to ten thousand Pounds, ... by these prodigal Strategems, than in Half the Town beside. And all for Want of proper Fore-thought, in estimating the certain Issues and the uncertain Gains, with proper Allowance for unavoidable Losses, by some Customers who cannot pay, and others who will not. Some who are above the Reach of the Law, and others beneath it." Again, though the author lauds friendship and service, he nevertheless cautions his son never to engage in "Bonds," "Notes," or "Securities" for a friend and even to consider such a request as a breach of friendship, for "I have seen as many men dragged into Ruin by these fatal Incumbrances, as by a Life of Riot and Debauchery."

Many of the passages in this little book, moreover, are not lacking in humor, as may be exemplified by the discourse therein on "Horse Keeping." The author commences by saying that though riding is both an innocent and a manly sport and though he had formerly recommended it to his son, he has now lived long enough to retract much that he had formerly advised and to "see Cause to dissuade you from ever keeping a Horse; at least, till your Circumstances, or improved Sagacity, render it allowable; or your Health or Business necessary." He then cites the instance of a young tradesman acquiring a horse and then "Opportunities are panted for of producing his new Equipage, and sharing in the Frolicks of the Age. Seats, Palaces, public Places are first visited in Turn." Then follow horse races, hunting matches, gaming, drinking, country lodges, etc. But the worst consequence in the eyes of this worthy author is that "Business is cramped into one Half of the Week, that Pleasure may be indulged during the rest." Servants are then entrusted with the management of the business and they seldom fail to "put in for their Share of the Plunder," all of which chain of evils ends in bankruptcies and ruin.

He closes his discourse with advice on courtship and marriage, cautioning his son to beware: "When, therefore, either by Accident or Choice, you venture into their (women's) insinuating Company, consider them all as Syrens, that have Fascination in their Eyes, Music on their Tongues, and Mischief in their Hearts"! 
Does the pragmatic value of such advice in the early Georgian period account for the fact that this "Present for an Apprentice" went through at least ten editions?

\section{Notices}

\section{A SUPPLEMENT TO THE OCTOBER BULLETIN}

Members of the Society will be interested in the fact that the number of accessions which the Society received during the summer of 193I was so large that it was deemed advisable to print this list in a Supplement which will be mailed to our members on the same date as the regular issue of the Bulletin.

\section{A CORRECTION}

An error in the Bulletin for November, 1930, has been called to our attention. The article, "Cargoes of Colonial Ships," referred to Captain Nathan Lord, who was sailing ships out of Portsmouth in 1790, as being of Kennebunkport and the father of Daniel Walker Lord, shipping merchant of Kennebunkport from 1820 to the postCivil War period. Further investigation shows that the father of Daniel Walker Lord was Nathaniel Lord, also a shipping merchant of Kenneburkport, while the Nathan Lord referred to in the article was really of Kittery, Maine, and belonged to another branch of the family.

The error arose from the similarity of the names and professions and from the fact that the two men were contemporaries. We are glad to have had this error called to our attention.

\section{LOAMMI BALDWIN AND THE TOWN THAT BEARS HIS NAME}

With reference to an article entitled "The Baldwin Collection" appearing in the Bulletin of the Business Historical Society for May, I93I, we take pleasure in printing the following letter correcting a possible misinterpretation of the article:

To the Editor of the Bulletin

of the Business Historical Society:

The author of the very interesting paper upon the Baldwin Collection which appears in your May number falls into one error which ought to be 